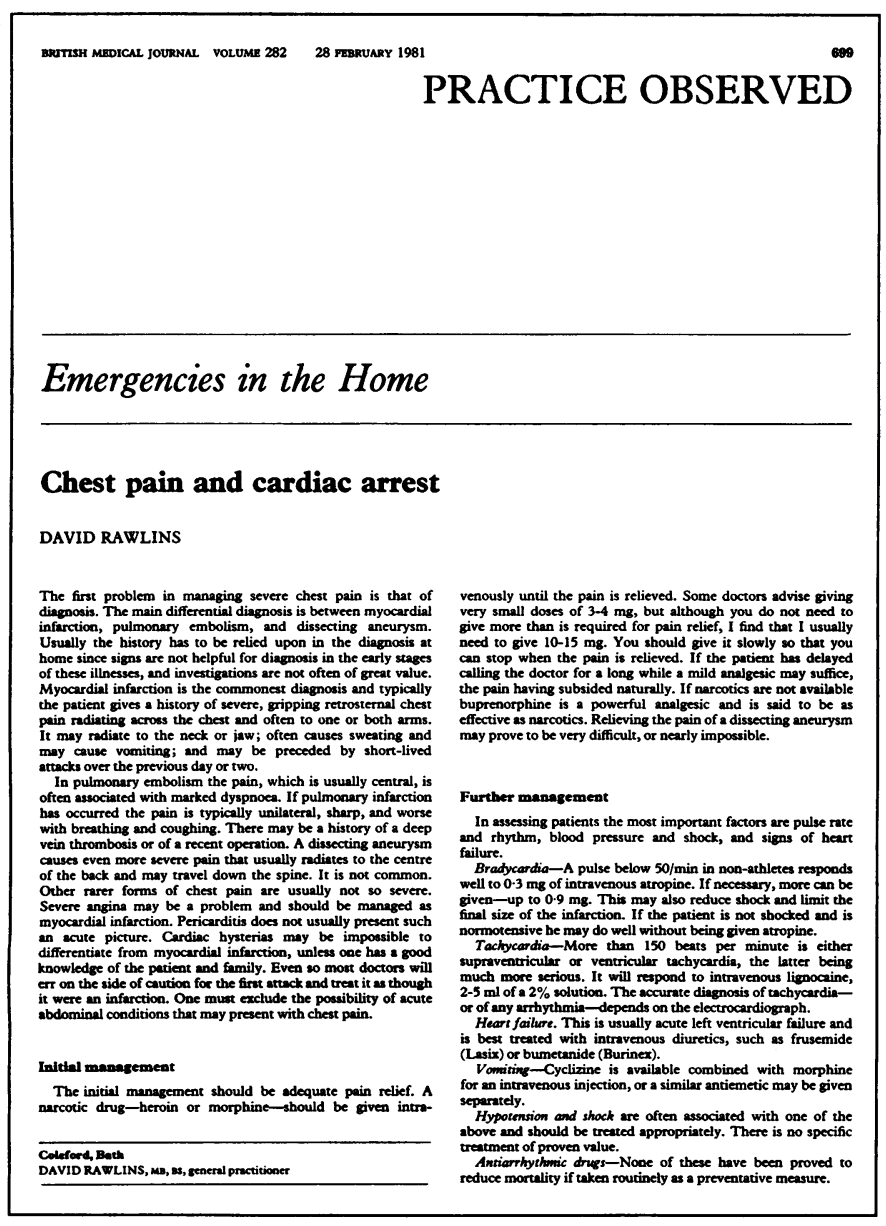

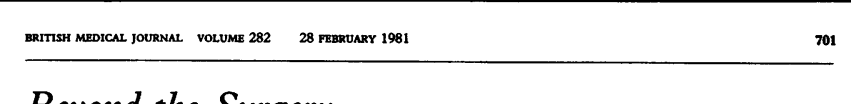

\title{
Beyond the Surgery
}

\section{General practitioner at school}

H G BARNES

Since $1969 \mathrm{I}$ have been school medical officer to the Newcostle
Royal Grammar School. I succededed Dr Andrew Smith in a job

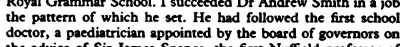

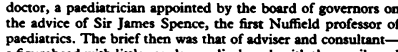

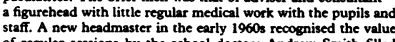

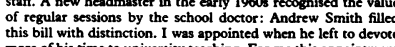

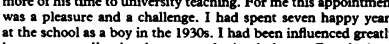

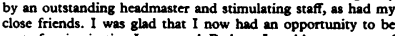

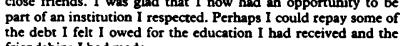

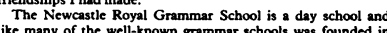
like many of the well-known grammar schools was founded in
bifuf

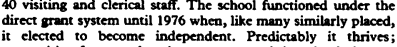

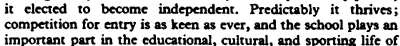
Newcastle.
Is started with a fecling of anxiety and strangeness in my new

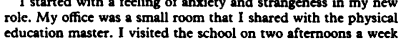

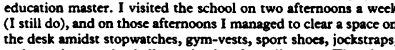
embrocation, rugby balls, and other impedimenta. The chaos
and sweary arome of this office did nothing for my medical image

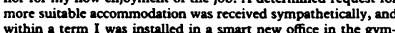

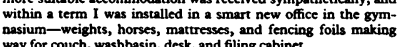

Looking after 1000 boys

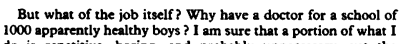

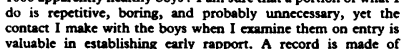

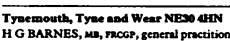

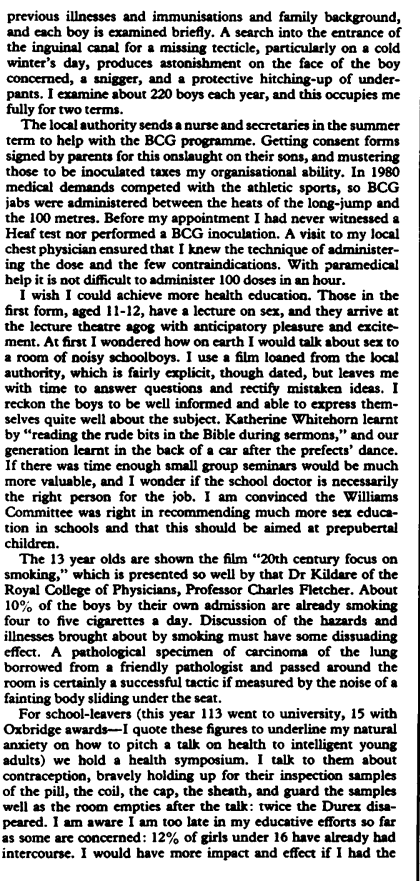

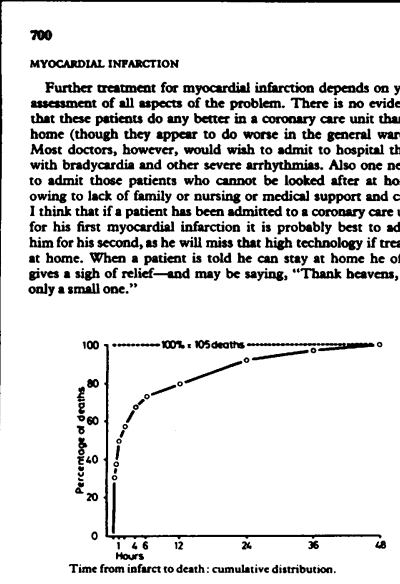

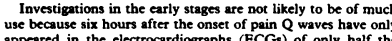

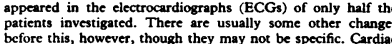

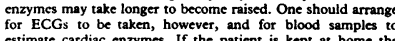

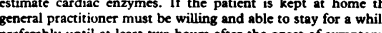
preferably untili at last twe hours sfter the onset of symptoms
He should be willing to revisiti the same day if necessary and on daily basis for the nert few days. It is best to get the patient
moving affer not more than two or three days in teded Patient always be admitred to hospital.
Cardiec arrest-The most hazrdous time is the first feur

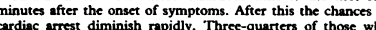

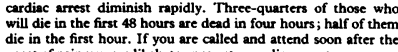
dic in the first hour. If you are called and attend soon affer the
onset of pain you are cikcly to encounter cardiac arrest.

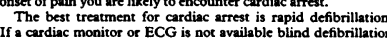

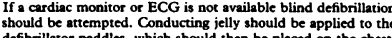

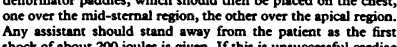

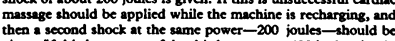
be made. This should be done before any orher artempors

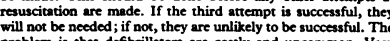

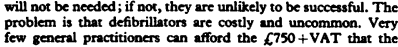

BRITISH MEDICAL JOURNAL VOLUME $282 \quad 28$ FeBRuARY 198 cheapest (Pantridgec) model costs, and no other agency has
shown much incerest supplying those who need them. A few shown much interest supplying those who need them. A few
ambulances are equipped, and almost all district general
hospitals and most cortege of general prectitioner hospitals have them.
If a defibrillator is not available, a sharp blow on the chest may occasionally be successful and is cerrainly worth trying. If it is not successful, cardiopulmonary resuscitation-cardiac massage
and some form of ventilation such as mouth-to-mouth - should and some form of ventilation such as mouth-to-mouth-should
be started in the hope that the patient might be defibrillared Cardiac massage-If the patient's heart stops he will rapidly resuscitation is antempred, the more likely it is to be sucossffu. Cardiac massage is best given with the patient on a firm surface. 11-2"- at a rate of about 60 per minute. A short, sharp thrust is
most effective, and the recovery phase should be as long as
possible so that the heart can fill. You should continue for five compressions before your assistant inflates the lungs. If you are
alone you can go on for 15 beans before inflating the lungs. If cardiac masssege is sulccessful and produces an adequarte circula
tion the patient will regain consciousness and start to breathe spontaneously. I do not think that anyone can continue cartiac massage on a struggling paticent for very long. If the patient
remains unconscious, and provided the pupils do not become dilated and fixed, it may be possible to transport him to
defibrillator but the chances of a full recovery diminish with every minute.
Ideally, every general practitioner would carry a defibrillato and be confident in its 1 use, , and every a ambulannce would be
equipped with one. If possible, while one or two people ureem equipped with one. II possible, while one or two people attemp
cardiopulmonary resusciation another establishes an intra venous line giving sodium bicarbonate 1 mol(mEq)/n per $\mathrm{k}$
body weight to help correct the acidosis. Half this dose should fe given every 10 minutes. If resuscitation from ventricular

The "caft coronary"

This cause of sudden death, although it does not usually
occur in the home, should be briffly mentioned. A bolus of

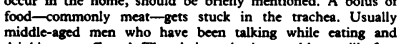
middle-aged men who have been talling while cating an
drinking are affected. The victim, who in speechless, will often drinking are affected. The victim, who is speechless, will offte
grabb at his throat and be terrified. The quickest and best treatment is to get behind the victim, encircle his chest or upper
abdomen with your arms, and give 2 sudden sharps squecese,
anelling the bolus wirh a biast of the victim's expired air (the Heimlich manoeuvre).

I should like to thank Dr R D Thomas, consultant cardiologist at
the Royal United Hospital, Bath, for his advice.

THovch I have endeavoured to render this Treatife plain and uffeful,
yet I found it impoofible to avoid fome terms of art; but thofe are, in general, either explained, or are fuch as molt people undertlas

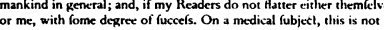
caly a matter as fome may imagine. To make a fhew of cerrning
eafier than to write plain fenffe, efpecially in a fcience which has beren kept at fuch a dittance from common oblervation. It would, however be no diffcult matter to prove, that every thing valuable in the practing
part of Medicine is within the reach or common abilites.
(Buchan's Domessic Medicine, 1786)

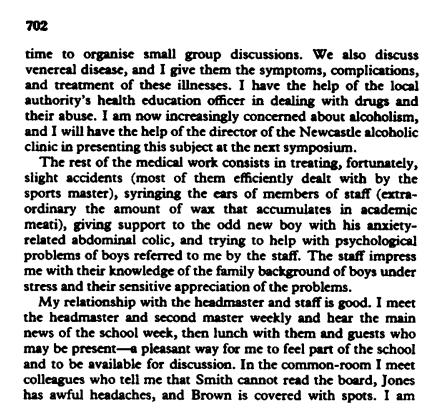

BRITISH MBDical JOURNAL VOLUME $282 \quad 28$ FranUARY 1981 also expected to give advice about their own children whom I do
not know and have never met, the menstrual irregularities of cheir wives, and the geriartric execesses of their parents-in-iav. in France), given new recipes (I like to try my hand at cooking),
and, most important, am offered warm friendship by a group professional people whose company I enjoy and whose knowGeneral practitioners as doctors to other schools will no doub anhieve more than I. Obviously those who are doctors to board-
ing schools and whose pupiss are regeistered patients will have a closer relationship and have gereater responsisibitity, but I suspect
that there are few who enjoy the iob more than I. For I am chool doctor when a few of those who taught me were stil teaching. I have made good friends with colleagues whose
interess li curstide medicine, and with other docorrs doing he
same iob who are members of the Medical Officers of School Associa na. And $1 \mathrm{am}$ stimulated and have pleasure in being drama, science, sports, and in many other activities never cease
to astonish me.

\section{Medical Records}

\section{History of our records}

IAN TAIT

I think that medicine, for a learned profession, is sadly neglectul
of its own history. A historical perspective often helps us co see

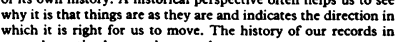
general practicec has much to teach us.
It somectimes scems that our present record system is assumed

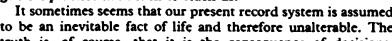

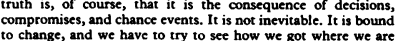
to changs, and we have to try to see how we got where we are
and what we now have to do to achieve the kind of records we

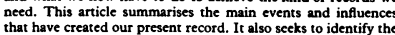
that have created our present record. It talso secks sto identify the
main reasons for our apparent inabbility to introduce changes in

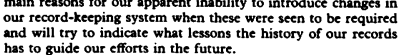

Beginnings:

We can trace the origins of our record system to Lloyd
George's National Insurance Act of 1911 . Under that Act the

Nadburrgh, Suffolk male working population between the ages of 16 and 70 werc provide medicas lerevices for insured patients. The Government he health of the working population that might be made avai-
ble as a result of the medical care given under the terms of the Act. For this reason the Act included a clause that imposed upon gention "ractitioners tho participated in the scheme an obli-
hem such medical records as might be required of TIN BoxEs

In 1913 a form of record was introduced for this stacistical
purpose. At the end of the year the doctor was required to return purpose. At the end of the year the doctor was required to return
his record for analysis. For our purposes, the only interesting to keep them. These records were in use until 1917 , when they were given up as a temporary wartime measure. After the first
world war the question of what kind of record should be kept $b$. general practitioners had to be reconsidered. An advisoory com-
mitree (the Rollesson Commitree) was set up in 1920 with the
following terms of reference. "To consider and advise the Minister of Health and the
Scortish Board of Health as to the form of medical record to be Scortish Board of Health as to the form of medical record to be
prescribed under the conditions of service for medical practi- 


\begin{tabular}{|c|c|}
\hline & \\
\hline wes fascinat & Early reformers \\
\hline & During the carly 1960 s defects in the $\mathrm{ra}$ \\
\hline 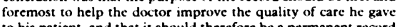 & 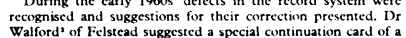 \\
\hline 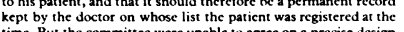 & 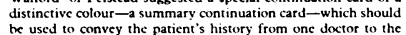 \\
\hline 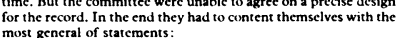 & 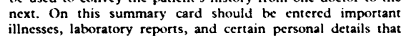 \\
\hline & $\begin{array}{l}\text { have a profound dffect on the medicial lifo of } \\
\text { advocarted fixing continuation cards in } \mathrm{ch}\end{array}$ \\
\hline 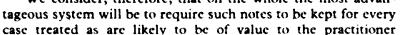 & 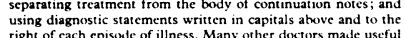 \\
\hline 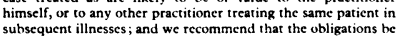 & 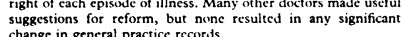 \\
\hline & 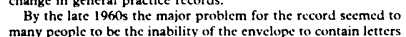 \\
\hline 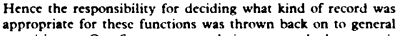 & 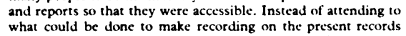 \\
\hline 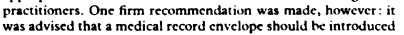 & 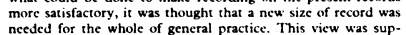 \\
\hline 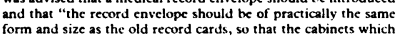 & 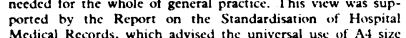 \\
\hline & 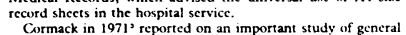 \\
\hline 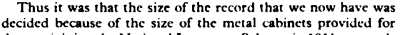 & 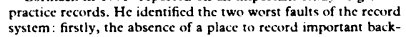 \\
\hline 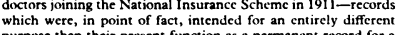 & 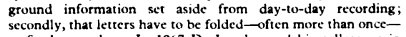 \\
\hline 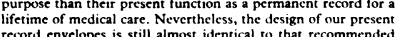 & 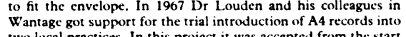 \\
\hline 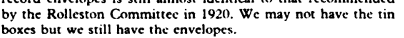 & 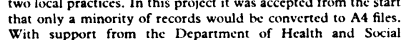 \\
\hline & 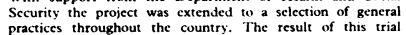 \\
\hline AS LEFT TO US & $\begin{array}{l}\text { suggested that general } \\
\text { duction of } A \text { A records. }\end{array}$ \\
\hline 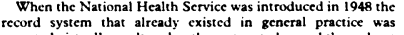 & 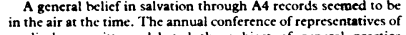 \\
\hline 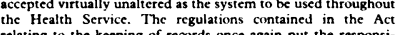 & 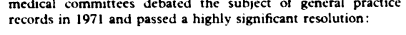 \\
\hline 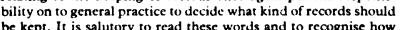 & 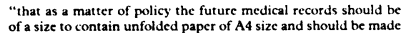 \\
\hline wc hat & 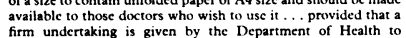 \\
\hline 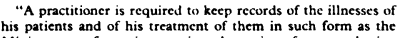 & $\begin{array}{l}\text { financec all consequent } \\
\text { arising therefrom." }\end{array}$ \\
\hline $\begin{array}{l}\text { Ensultation } \\
\text { Entative of the }\end{array}$ & The qualifying conditions should be nored. This resolution \\
\hline $\begin{array}{l}\text { gencerat body of medidaca practitionects. } \\
\text { The clinical recerd should contain all information that would }\end{array}$ & 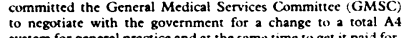 \\
\hline 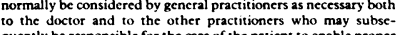 & \\
\hline 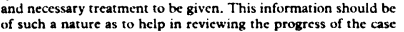 & \\
\hline 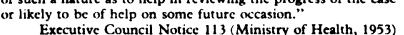 & NO FUNDS, NO CHANGE \\
\hline cil N & $\begin{array}{l}\text { king party in the } \\
\text { ice. Its trerms of }\end{array}$ \\
\hline 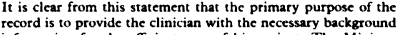 & \\
\hline 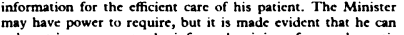 & 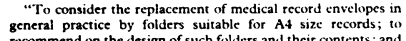 \\
\hline $\begin{array}{l}\text { only yect in response to the informed opinion of general practi- } \\
\text { tioners themselves. Gencral practice has bern sliow to accept }\end{array}$ & 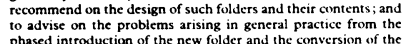 \\
\hline 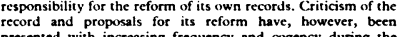 & $\begin{array}{l}\text { Phased introduction of the new folder and the conversion of the } \\
\text { existing records." }\end{array}$ \\
\hline 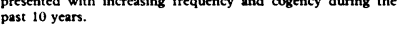 & The long labours of the jiint commintec ended in nothing. They \\
\hline
\end{tabular}

\begin{tabular}{|c|c|}
\hline 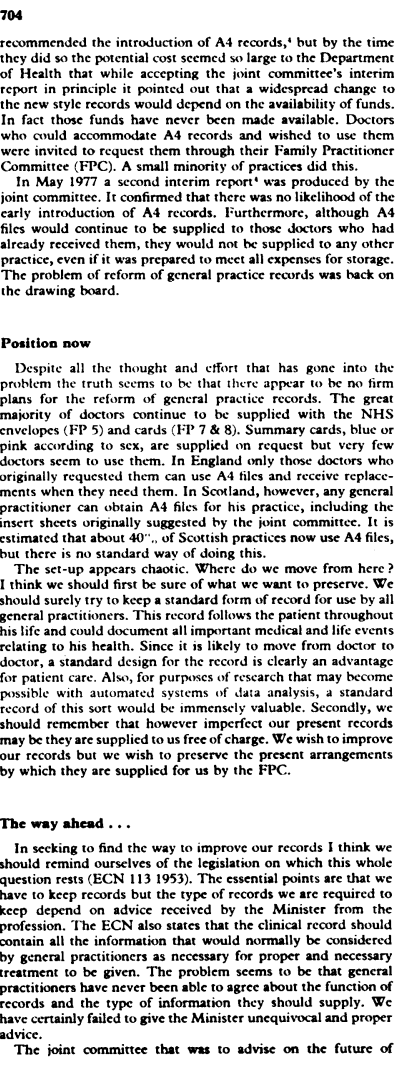 & 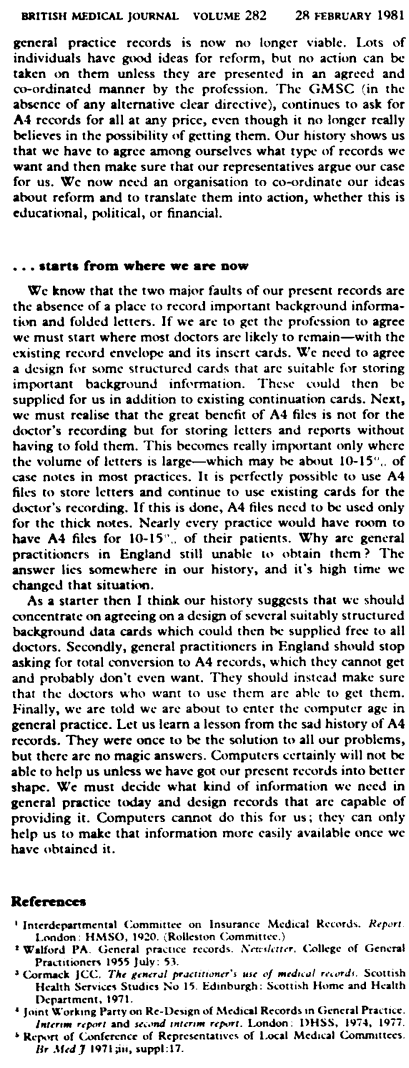 \\
\hline
\end{tabular}

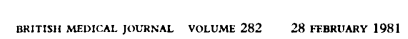
705

\section{Pitfalls in Practice}

\section{Situation vacant}

II: The "doctor's right hand"

JOHN OLDROYD

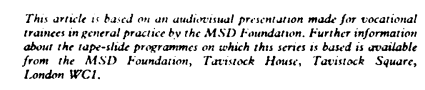

Dr Brian Bumble, a gencral practitioner in Mudhamptonshirc.

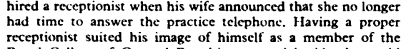
Royal College of General Practitioners, and besides he could
get $70^{\circ}$, of the cost back from the family practitioner commintec

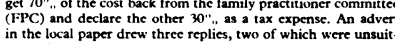

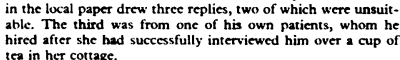

Nerve centre of the practice

We pick up our tale two ycers and a day aftect the Monday
morning on which Mrs Prudence Pratliter joince Dr Bumble's

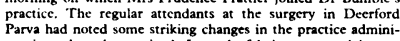

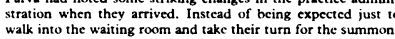
ing buzzer to sound, they must first present themselves to Mrs
Prattlet at her counter in the clobby. This is clearly the nerve

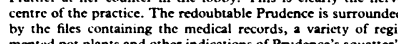

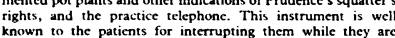

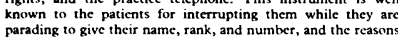

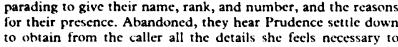
sort the frivolous from the serious.
Dr Bumble was not at all sure whether he approved of the

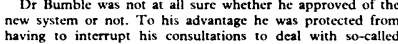

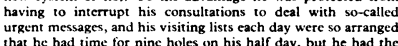

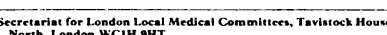

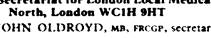

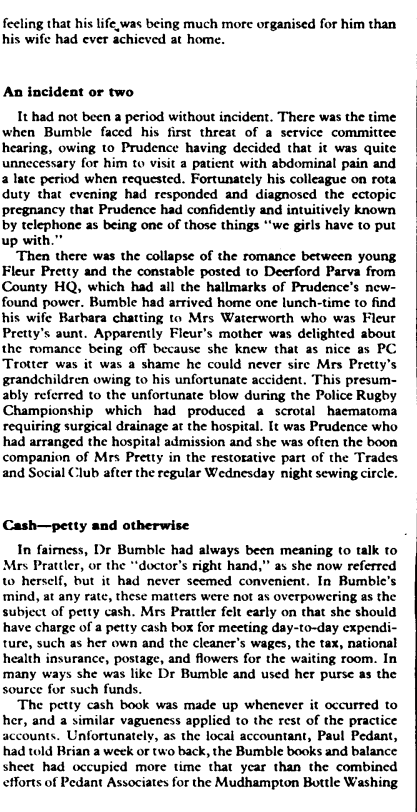

\section{6}

Machinc Company. He doubted even if Brian could afford his
firm's account,

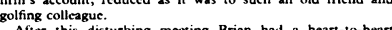

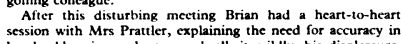

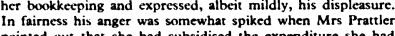

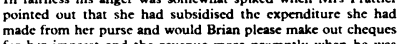

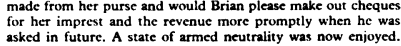

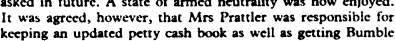

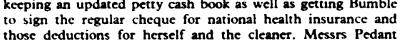

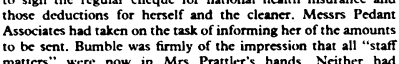

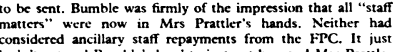

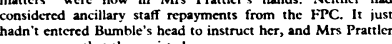
A puzzling letter

Dr Bumble was poorly prepared for the shock that was in
store for him two ycars and a day affer Mrs Practler had started

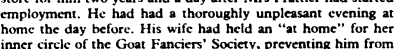

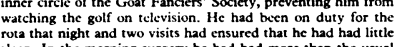

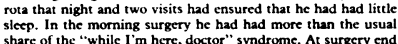

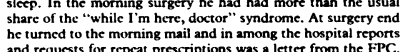
Dear Dr Bumble,

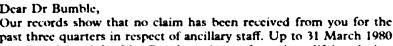

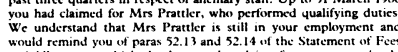

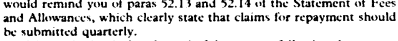

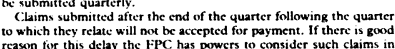

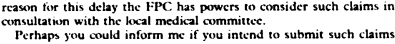

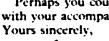

Samuel sponer

Samucl Spoxner
Administrattur

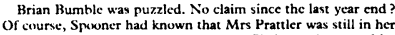
post. Therec had been unpleasanteress at Christmas between him
and Prudicnce when he had had to call twice for his regular

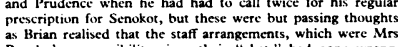

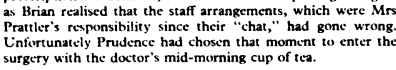

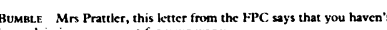

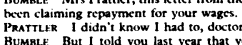

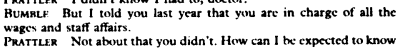

BRITISH MEDICAL JOURNAL VOLUME $282 \quad 28$ FrBRUARY 1981

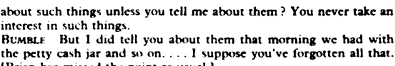

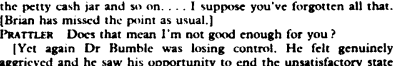

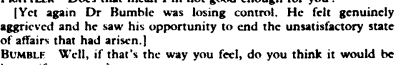

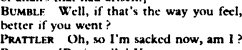

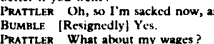

.

Mrs Prattler left with a brave face, returned with the petty
cash box, counted out two wecks' wages in front of Brian, and

It is worth noting that:
(1) no jobt description had been properly made;
(2) no statement of contract had becn made, which should

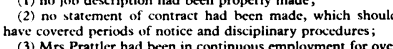
(3) Mrs Prattler had been in continuous employment for over
52 wecks at more than 1 h hours a week;
(4) she had committed two errors where she could rightly have

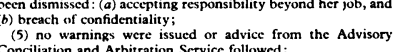
(6) the item provoking dismissal was not necessarily her fault;
(7) during his last interview with Mrs Pratter, Dr Bumble (7) during his lass interview with Mrs Pratilter, Dr Bumble
should have bece clear in his mind about just what action he

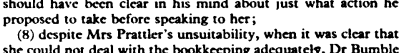
she could not deal with the bookkecping adequatecy, Dr Bumble
should have remembered that each principal can obtain up to should have remembered that each principal can obtain up to
$70^{\prime \prime}$ reimbursement for two whole-time equivalents. He should
have considered appointing someone to share the ducies with
Mrs Prattler. Unfair dismissel

Prudence may have gonc, but she was not forgoten. A week
after Dr Bumble had dismissed Mrs Prattler he received a

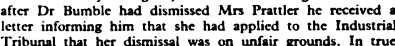
Tribunal that ther dismissal was on unfrair grounds. In truc
Bumble fashion Brian took no notice of thesc papers for severa weeks. He was far too involved in the complexitises of tax and
national health insurance deductions and sending out a $P 60$. Consequently, insen he did think of of doing sonemething about it,
it was too latc. The regional office of the BMA was very helpfol it was too late. The regional office of the BMA was very help
in advising him that the time had passed when he could in advising him that the time had passed when he could
acknowledge receipt of the original notice. Fourten days is the
limit. They pointed out that this meant that he had lost his opportunity of taking further part in the case but said they would
be only too willing to advise him if he had a similar problem in the future.
Thus he was precluded from: (a) asking further particulars of the application;
(c) (a) asking further particulars of the application;
(b) asking for witness orders;
(c) asking for orders for discovery of documents; (d) submitting written representations;
(e) being heard, or represented, at the hearing: (f) applying for a review of the decision.
If Dr Bumble had known more about his rights and duties as an employer instead of relegating such matters to the bottom 